901 Joseph J. Sockalosky, Lawrence M. Dolan, Thomas cal School; Dept. of peds., Mp1s.

Hypercalcemia presents difficult problems of diagnosis and therapy. Recent studies in adults and animal tumor models have established that prostaglandin excess can be etiologic. The resultant hypercalcemia is responsive to inhibitors of prostaglandin synthetase.

A 6 week old female with subcutaneous fat necrosis and hypercalcemia was unresponsive to treatment with furosemide-saline diuresis, corticosteroids, low calcium feedings, and vitamin $D$ elimination. Rather than using more toxic therapy, a trial of aspirin (ASA) at $100 \mathrm{mg} / \mathrm{kg} / \mathrm{d}$ was Initiated. Serum calcium fell in 2 days to $10 \mathrm{mg} / \mathrm{dl}$ from a high value of 15 . It remained in the normal range thereafter except during attempts to lower ASA dosage at 14 days. A similar effect was noted in a second infant with subcutaneous fat necrosis. Calcium fell only to 13 $\mathrm{mg} / \mathrm{dl}$ from 18 , however, and diuretic therapy was successfully added. In both patients, elevated serum triglyceride levels also responded rapidly. A third infant with hypercalcemia, nephrocalcinosis and trisomy 21-22 mosaicism was treated. ASA rapidly lowered serum calcium to normal. ASA was discontinued after 13 days without exacerbation. Despite extensive clinical studies in each case, no definitive mechanism for hypercalcemia was found. These preliminary case studies suggest a role for prostaglandins in certain hypercalcemic states as well as a potentially safe form of therapy.
HYPERCALCEMIA RES PONS IVE TO ASPIR IN. Robert M. Ward

904

HEMOGLOBIN A $\mathrm{A}_{1}$ C AND "TIGHT" BLOOD GLUCOSE CONTROL IN NEWLY DIAGNOSED JUVENILE DIABETICS Mary E. Witt and Sinai School The recent demonstration that ments correlate with integrated blood glucose levels over the preceding 1 to 2 months and the mounting experimental evidence that maintenance of normal blood glucose levels may reduce diabetic complications, suggests that early vigorous treatment of newly diagnosed juvenile diabetics, monitored by $\mathrm{Hb} \mathrm{A}_{1} \mathrm{C}$ measurements, may be important in the long-range managements of these children. Fifteen youngsters, ages 3 to 18 , were studied at the time of diagnosis of insulin-dependent diabetes and sequentially at 1 to 2 months intervals. Initial concentrations of $\mathrm{Hb} \mathrm{A}_{1} \mathrm{C}$ were $8.6+1.28$ of total hemoglobin (normal, non-diabetic children $2.2-4.88)$, indicating the presence of hyperglycemia for a significant period of time prior to diagnosis. Within 4 to 6 weeks after diagnosis and placement of the children on a therapeutic regimen designed to promote normoglycemia, $\mathrm{Hb} \mathrm{Al}_{1} \mathrm{C}$ values declined to $5.4+0.98$ and were maintained at these levels in 12 of the 15 patients for periods ranging up to one year. No significant hypoglycemic reactions occurred in any of the children on the "tight control" protocol which included high protein meals plus 3 snacks per day, daily afternoon exercise and a combination of intermediate and short acting insulin given once or twice per day. The results indicate that it is possible to maintain insulin dependent diabetic children in a relatively euglycemic state that can be monitored sequentially by $\mathrm{Hb} \mathrm{A}_{1} \mathrm{C}$ determinations.

\section{GROWTH HORMONE (GH) MODULATION OF VITAMIN D}

02 METABOLISM. Yosef Welsman, Gail Knox, Edward Refter, All Children's Hospital, St. Petersburg, Florida.

Vitamin $D_{3}$ is hydroxylated in the liver $(C-25)$ and then in the kidney $(\mathrm{C}-1)$ to produce $1,25(\mathrm{OH})_{2} \mathrm{D}_{3}$. To study pitultary influence upon this sequence, intact (I) or hypophysectomized (H) 30 day male rats were maintained on a Vitamin D-deficient diet for 28 days. During the last 14 days, daily s.c. injections of diluent were given to $\mathrm{I}$ and $\mathrm{H}$; other $\mathrm{H}$ received $2 \mathrm{mg}$ bovine $\mathrm{GH}$ or prolactin (Prl). $12 \mathrm{~h}$ prior to the last injection, radiolabeled $D_{3}$ or $250 \mathrm{HD}_{3}$ was injected 1.p. and $26 \mathrm{~h}$ later the animals were sacrificed. After extraction, the radiolabeled metabolites in plasma, small intestine and bone were separated on Sephadex LH-2C columns. The \% radioactivity as $250 \mathrm{HD}$ was higher in serum of $\mathrm{I}$ (25\%) than in $\mathrm{H}(10 \%)$, and GH treatment restored levels to norma (20\%). A similar pattern was seen in small intestine and bone. $\%$ radioactivity as $1,25(\mathrm{OH}){ }_{2} \mathrm{D}_{3}$ was higher in $\mathrm{I}$ in intestine $(27 \%)$ bone $(15 \%)$ and plasma $(12 \%)$ than in $H(2.7,1,1.3 \%)$ and $1 n-$ creased in $\mathrm{H}$ after $\mathrm{GH}$ treatment $(9.6,5.2,2.3 \%)$. In I mantained on a D-adequate diet for 4 weeks, serum $250 \mathrm{HD}(23.9 \pm 5.5(\mathrm{SD}) \mathrm{ng} / \mathrm{ml})$ was higher than in $\mathrm{H}(12.3 \pm 3.2, \mathrm{p}<.01)$. $\operatorname{Pr} 1$ had no ef fect upon serum ${ }^{3}-250 D_{3}$, but partially restored levels in intestine and bone; Prl did not affect la-hydroxylation. Conclusions: 1) The anterior pituitary is important for 25 - and 1a-hydroxylation of Vitamin D; 2) GH and possibly Prl stimulate hepatic 25-hydroxylase activity; 3) $\mathrm{GH}$ enhances renal 1 $\alpha$-hydroxylation; 4) GH may be a regulator of calcium homeostasis through these mechanisms.

\section{3} SERUM 24,25 DIHYDROXYVITAMIN D $(24,25(\mathrm{OH}) 2$ D) LEVELS Y. Weisman, G. Lum,E. Reiter,N. Gilboa and A. Root. Depts. of Peds., USF College of Medicine, Tampa, and Univ. of Colorado Medical Center, Denver.

Serum concentrations of $24,25(\mathrm{OH})_{2} \mathrm{D}$, a metabolite of Vitamin D synthesized mainly by renal $250 \mathrm{HD}-24$ hydroxylase, and of $250 \mathrm{HD}$ were measured in normal and uremic subjects by competitive protein binding radioassay after isolation by Sephadex LH-20 chromatography. The mean ( $\pm \mathrm{SE}$ ) concentration of $24,25(\mathrm{OH}) 2 \mathrm{D}$ in 10 hemodialyzed children (H) (creatinine clearance $(\mathrm{CrCl})<5 \mathrm{ml} / \mathrm{min}$ ) $\left.1.73 \mathrm{~m}^{2}\right)$ was significantly ( $\left.\mathrm{p}<01\right)$ lower $(.87 \pm .13 \mathrm{ng} / \mathrm{m} 1)$ than in 12 normal children $(2.98 \pm .45)$. Mean serum $24,25(\mathrm{OH}) 2 \mathrm{D}$ in 10 azotemic children not requiring hemodialysis ( $\mathrm{CrCl}>5-100$ ) was also lower $(1.30 \pm .12, \mathrm{p}<01)$ than in normal children, but highe $(p<05)$ than in H. Mean radioassayable 250HD concentrations were similar in all groups. Serum $24,25(\mathrm{OH})_{2} \mathrm{D}$ levels and $24,25(\mathrm{OH})_{2} \mathrm{D} / 25 \mathrm{OHD}$ ratios correlated significantly with $\mathrm{CrCl}$ ( $\mathrm{r}=$ $.62, \mathrm{p}<01$ and $\mathrm{r}=.76, \mathrm{p}<01$, respectively) when all subjects were analyzed. In a group of 6 anephric adults, serum $24,25(\mathrm{OH}){ }_{2} \mathrm{D}$ leve1s $(.55 \pm .20)$ were lower ( $\left.<<01\right)$ than in 18 normal adults $(1.70 \pm .15)$ and undetectable in 3 . Conclusions: (1) $24,25(\mathrm{OH})_{2}$ D, an easily measured vitamin $\mathrm{D}$ metabolite; (2) $250 \mathrm{H}$ levels do not differ from normal in patients with renal insufflency; 3) Diminished $24,25(\mathrm{OH})_{2} \mathrm{D}$ values may parallel renal l-hydroxylase activity which is also decreased in uremia; (4) Lowered $1,25(\mathrm{OH}){ }_{2} \mathrm{D}$ and $24,25(\mathrm{OH}){ }_{2} \mathrm{D}$ production may both contribute to the development of renal osteodystrophy.
905 FAT-CARBOHYDRATE INTERRELAT IONSHIPS: THE ROLE OF GLUCOCORTICOIDS. Joseph I. Wolfsdorf and Boris Senior. Metabolic Service. Boston.

A lack of glucocorticoids causes fasting hypoglycemia. This is usually ascribed to impaired gluconeogenesis from protein. examined the metabolic response of adrenalectomized (adrenx)rats to fasting.

Adrenx rats ( $n=32$; confirmed by corticosterone assay), after $<0.025$ ), free fatty acids (FFA) (781士 $38 \mathrm{vs}$. $1010 \pm 44 \mu \mathrm{Eq} / 1$; p $<0.001)$ and ketones $(2.4 \pm 0.24$ vs. $5.56 \pm 0.33 \mathrm{mM}$; p po.001) than sham-operated controls $(n=27)$.

Intramuscular cortisone acetate $(0.5 \mathrm{mg} /$ day) raised the fasting levels of FFA $(830 \pm 85)$, ketones $(3.46 \pm 0.65)$ and glucose $(69.7 \pm 4.0)$. The urinary excretion of urea nitrogen in the adrenx rats exceeded that of controls $(263.2 \pm 14.3 \mathrm{vs} .166 .7 \pm 14.0 \mathrm{mg} /$ 48 hours; $\mathrm{p}<0.001$ ), and was not increased by the glucocorticoid therapy (253.3 14.7 ).

Clearly, glucocorticoids did not raise the glucose in the drenx rats by enhancing gluconeogenesis from protein.

FFA and ketones are major fuels of fasting. A lack would ncrease glucose oxidation and predispose to hypoglycemia. We conclude that glucocorticolds do not sustain fasting levels of glucose by enhancing gluconeogenesis from protein but by reducing the consumption of glucose through greater avai1ability and utilization of fuels derived from fat. 906 EFFECT OF EARLY FEEDING ON PLASMA GLUCOSE IN SMALLRecent evidence that fasting glucose homeostasis is 1 imited in newborns by an impairment in gluconeogenesis suggests that the high incidence of hypoglycemia (hypogly) in SGA neonates may reflect the extent of fasting imposed on them by nursery feeding practice. To evaluate the effect of early feeding on plasma glucose (glu) levels, 18 healthy SGA infants (10\%ile, 35-41 wk gest) were nipple-fed at 3 hour (hr) intervals starting within 2 hrs after delivery. Glu was measured before each feeding for the first $25 \mathrm{hrs}$ of life. 11 healthy SGA infants in whom feedings were routinely witheld until $8 \mathrm{hrs}$ of age served as controls. Mean $( \pm S E M)$ glu prior to feed $\# 1$ was $59 \pm 7 \mathrm{mg} / \mathrm{dl}$ and then ranged between $63 \pm 4$ and $73 \pm 5 \mathrm{mg} / \mathrm{d} 1$. None of the $143 \mathrm{glu}$ then ranged between $63 \pm 4$ and $73 \pm 5 \mathrm{mg} / \mathrm{d} 1$. None of the $143 \mathrm{glu}$
values was $<35 \mathrm{mg} / \mathrm{d} 1$. Only $3 / 18(17 \%)$ early fed infants had a glu $<40 \mathrm{mg} / \mathrm{dl}$ (all prior to feed $\# 1$ ) vs $8 / 11$ ( $73 \%$ ) control infants $(p=.02)$. After the first feed, none of the early fed infants had a glu $<40 \mathrm{mg} / \mathrm{d} 1$.

These data indicate that glu is maintained in SGA infants at higher levels in response to early feedings. The current def inition of hypog1y in SGA infants (glu $<25 \mathrm{mg} / \mathrm{d} 1$ ), based on surveys of glu when feedings were routinely withheld for 24-72 hrs after birth, may underestimate the level of glu which is physiologically normal for these infants. The present study suggests that it is reasonable to raise the level of glu used to define hypogly in SGA neonates to that used in older children (40mg/d1). restabilization, were fasted for 48 hours. They exhibited lower levels of glucose $(55.2 \pm 3.3$ vs. $66.5 \pm 3.5 \mathrm{mg} / \mathrm{dl}$, mean $\pm \mathrm{SEM} ; \mathrm{p}$ Papadopoulos Univ of Pa, Dept of Ped, Children's Maria Delivoria 